\title{
Investigation of the Effect of Grain Refinement on the Mechanical Properties of 6082 Aluminium Alloy
}

\author{
Duygu Izcankurtaran, Bilgehan Tunca, Gökberk Karatay \\ Zahit Alüminyum Sanayi ve Ticaret Anonim Şirketi, Adana, Turkey \\ Email: d.izcankurtaran@zahit.com.tr
}

How to cite this paper: Izcankurtaran, D., Tunca, B. and Karatay, G. (2021) Investigation of the Effect of Grain Refinement on the Mechanical Properties of 6082 Aluminium Alloy. Open Journal of Applied Sciences, 11, 699-706.

https://doi.org/10.4236/ojapps.2021.116051

Received: May 7, 2021

Accepted: June 22, 2021

Published: June 25, 2021

Copyright $\odot 2021$ by author(s) and Scientific Research Publishing Inc. This work is licensed under the Creative Commons Attribution-NonCommercial International License (CC BY-NC 4.0).

http://creativecommons.org/licenses/by-nc/4.0/

\begin{abstract}
In this study, it is aimed to investigate effect of the grain refinement on the mechanical properties of the AA 6082. The micro structure which plays crucial role in determining the mechanical properties of the alloys is varied according to grain size, chemical composition and cooling rate. The prescription was prepared by determining the chemical composition range according to the standard (TSE-EN-573). The casting experiments were performed on the 6082 aluminium alloy which belongs to $\mathrm{Al}-\mathrm{Mg}$-Si system with different percentages of grain refinement $\left(\mathrm{AlTi}_{5} \mathrm{~B}_{1}\right)$ and chemical composition. Heat treatment that is homogenization and artificial aging was applied after casting and extrusion process, respectively. The microstructure analysis and mechanical tests were done on the produced samples in order to understand the structural and mechanical strength of the material. The experimental results showed that using the grain refinements is contributed to increasing the mechanical properties. It was observed that the mechanical strength values increased by $17 \%$ after the reduction of the grain size by $69 \%$ with the $0.11 \%$ addition of the $\mathrm{AlTi}_{5} \mathrm{~B}_{1}$ master alloy.
\end{abstract}

\section{Keywords}

Aluminium Alloys, Grain Refinement, Solidification, Mechanical Properties, Casting

\section{Introduction}

Aluminum alloys have superior mechanical properties due to having low density, high specific strength, high corrosion resistance, and ability to improve their mechanical properties, and ease of shaping and processing. Those prior proper- 
ties make them useful in many industries such as automotive, transportation, aviation-space, electronics, machinery and manufacturing. Especially in the automotive, aerospace and aviation sectors, it plays a very important role in providing fuel savings and preventing air pollution by reducing weight due to their low density. One of the most widely used aluminum alloys is 6XXX (Aluminum-Al, Magnesium-Mg, Silicon-Si containing) alloys [1]. Aluminum has a low melting temperature and can be alloyed with other alloy elements in atmospheric conditions, which increases its castability. Continuous casting of aluminum alloys is a widely used method in industry for producing long pieces of specific cross-sections. Continuous casting is based on the principle of transforming the molten metal into a solid state by passing it through an open-ended mold whose outer surface is cooled with water and simultaneously passing the same amount under the mold [2]. EN AW 6082 is among the high strength Al-Mg-Si alloys preferred for structural profile applications. In EN AW 6082 alloy, the amount of Silisyum ( $\mathrm{Si}$ ) is more compare to Magnesium $(\mathrm{Mg})$ in order to increase the aging hardening capacity while Manganese $(\mathrm{Mn})$ provides the control of the grain structure. For high strength, the process should be designed to prevent partial crystallization or to give a fine yarn-like grain structure in the entire cross section [3]. In Al-Mg-Si aluminum alloys, it may be necessary to add some alloying elements with appropriate criteria in order to protect the structure under high temperature process conditions such as extrusion. The need for materials with fine and stable grain size can be provided by the production of materials containing precipitate particles that prevent the movement of grain boundaries and consequently grain growth [4]. Atoms move completely randomly in the melt at the melting temperature. During the solidification of liquid aluminum, the atoms attract each other so that one atom arranges itself closest to the other atom and the surface-centered cubic lattice structure of aluminum is formed. When the melt cools to $660^{\circ} \mathrm{C}$, crystallization nuclei are formed at different points in the liquid. These small nuclei increase rapidly in size as the aluminum atoms continue to line up around each nucleus. Grain growth ends when the melt is completely exhausted and the crystals come together at the grain boundaries [4]. One of the parameters that determine the mechanical properties of the part to be produced is the microstructure. Microstructure changes according to the grain size, modification level, chemical composition and cooling rate of the alloy. TiB master alloy was used during the experiments to adjust the grain size for the 6082 alloy belonging to the Al-Si-Mg system and determine the effect of the master alloy on the structure of the alloy. Magnesium ( $\mathrm{Mg}$ ) is an alloying element that contributes to enhancing the strength, corrosion resistance and weldability as well as increasing the rolling ability and machinability [5]. Adding Magnesium $(\mathrm{Mg})$ increases the mechanical properties of the alloy by creating precipitation of $\mathrm{Mg}_{2} \mathrm{Si}$ in the microstructure as a result of aging in aluminum alloys [6]. By adding Chromium (Cr) element to liquid metal, precipitate formation was provided, the microstructure was refined, and experimental studies were carried out to improve hardness and tensile strength [7]. In this study, $\mathrm{Al}$ - 
$\mathrm{Ti}_{5} \mathrm{~B}_{1}$ master alloy in rod form containing effective nucleating elements (titanium and boron) was preferred as a grain refiner in the casting process to obtain high quality AA6082.

\section{Material and Method}

Casting experiments were carried out according to the grain refining principle which is one of the most important parameters determining the mechanical properties of 6082 cast alloy. The mechanical properties of the products were investigated by making the solution (homogenization), extrusion and extreme aging processes under the same conditions after billet casting.

\subsection{Grain Refinement Theory}

Main purpose of aluminum billet casting is to obtain a structure consisting of fine and coaxial grains. Grain type and size of the billet varies depending on the chemical composition, solidification speed and grain refiners. Grain refiners improve the casting process by minimizing self-shrinkage, hot tearing and hydrogen porosity. Products obtained by extrusion of billets poured by grain refining process have better mechanical properties. It is more sensitive to heat treatment. They create better surfaces as a result of chemical and electrochemical surface treatments and are more resistant to surface tearing [8]. In this study, $\mathrm{AlTi}_{5} \mathrm{~B}_{1}$ master alloy in rod form containing effective nucleating elements (titanium and boron) was preferred as a grain refiner in the casting process. The primary role of grain refiners in Al-Si alloys is the controlled growth of grain structures by heterogeneous nucleation [9]. According to the grain reduction theory, Titanium is formed $\mathrm{TiAl}_{3}$ compound in the structure inducing heterogeneous nucleation points in the melt aluminium. During the cooling process, without the need for any overcooling, aluminum is nucleated on $\mathrm{TiAl}_{3}$ compound by a heterogeneous nucleation mechanism and the fine-grained structure is formed spontaneously [10] [11]. The chemical composition of the $\mathrm{AlTi}_{5} \mathrm{~B}_{1}$ master alloy used in grain refining studies is given in Table 1.

\subsection{Casting Process}

The experiment casting which has a chemical composition similar to 6082 alloy were performed for comparative analysis using by grain refinement method. The standard chemical composition of the 6082 alloy system is given in Table 2.

Table 1. $\mathrm{AlTi}_{5} \mathrm{~B}_{1}$ chemical composition.

\begin{tabular}{cccccc}
\hline Element (\%) & Ti & B & Si & Fe & V \\
\hline & $4.50-5.50$ & $0.8-1.2$ & $\leq 0.30$ & $\leq 0.30$ & $\leq 0.20$ \\
\hline
\end{tabular}

Table 2. EN AW 6082 standard chemical composition.

\begin{tabular}{ccccccccc}
\hline Element (\%) & $\mathrm{Si}$ & $\mathrm{Fe}$ & $\mathrm{Cu}$ & $\mathrm{Mn}$ & $\mathrm{Mg}$ & $\mathrm{Cr}$ & $\mathrm{Zn}$ & $\mathrm{Ti}$ \\
\hline Sample 1 & 0.95 & 0.38 & 0.008 & 0.55 & 1.15 & 0.0036 & 0.05 & 0.009 \\
\hline
\end{tabular}


Al-Mg-Si alloy which has a similar composition to EN AW 6082 alloy has been modified with three different Titanium-Boron additions. The design parameters of the casting experiments which belong to 6082 Aluminium Alloy that were preticted with Magnesium (1.20\%) and Crom (0.25\%) with $\mathrm{AlTi}_{5} \mathrm{~B}_{1}$ for investigation of the mechanical behaviour is given Table 3 .

\subsection{Heat Treatment Process}

The basic rule for the improvement of the mechanical properties in aluminum alloys; it is the distribution of very fine precipitate phase in the structure as a result of the aging process from the supersaturated solid phase. The formation of this precipitate phase can occur naturally or artificially. However, a very effective change in mechanical properties cannot be obtained with natural aging in aluminum alloys. There are basically three stages for aging to ocur, these are respectively; it is the process of solution heat treatment, quenching and precipitation (aging) [12]. In the T6 heat treatment of 6082 aluminum alloy, primarily the solution heat treatment process is applied at sub-eutectic temperature of $580^{\circ} \mathrm{C}$ for a long time to form the precipitate phase in solid solution. Magnesium and some silica dissolve and form a homogeneous form in the solution heat treatment process. Performing the aging process at $180^{\circ} \mathrm{C}$ causes the precipitation of magnesium and silica in aluminum dendrites as $\mathrm{Mg}_{2} \mathrm{Si}$. Castings with five different chemical compositions determined in the experimental study were made with the parameters given in Table 4.

\subsection{Metallographic Tests}

Microstructure examinations of the samples were made in Nikon dealer optic microscope after the homogenization process. Microstructure studies were carried out on bakelite samples prepared using known metallographic methods. The surfaces of the samples to be tested for hardness are cleaned and

Table 3. Casting alloy experiments.

\begin{tabular}{cccccccccc}
\hline $\begin{array}{c}\text { Element } \\
\text { (\%) }\end{array}$ & Si & Fe & Cu & Mn & Mg & Cr & Zn & Ti & B \\
\hline Sample 2 & $1.00-1.05$ & $0.35-0.37$ & 0.050 & 0.55 & 0.75 & 0.1 & 0.06 & 0.09 & 0.0061 \\
Sample 3 & $1.00-1.05$ & $0.35-0.37$ & 0.050 & 0.55 & 1.20 & 0.1 & 0.06 & 0.11 & 0.0070 \\
Sample 4 & $1.00-1.05$ & $0.35-0.37$ & 0.050 & 0.55 & 1.20 & 0.1 & 0.06 & 0.008 & 0.0005 \\
Sample 5 & $1.00-1.05$ & $0.35-0.37$ & 0.050 & 0.55 & 0.75 & 0.25 & 0.06 & 0.008 & 0.0005 \\
\hline
\end{tabular}

Table 4. Casting process parameters.

\begin{tabular}{|c|c|c|c|c|c|c|c|}
\hline Cooling & Casting & Casting & Casting & Homogenization & Homogenization & Aging & Aging \\
\hline $\begin{array}{l}\text { Temp. } \\
\left({ }^{\circ} \mathrm{C}\right)\end{array}$ & $\begin{array}{l}\text { Press. } \\
\text { (bar) }\end{array}$ & $\begin{array}{c}\text { Temperature } \\
\left({ }^{\circ} \mathrm{C}\right)\end{array}$ & $\begin{array}{l}\text { Velocity } \\
(\mathrm{mm} / \mathrm{sn})\end{array}$ & $\begin{array}{c}\text { Temperature } \\
\left({ }^{\circ} \mathrm{C}\right)\end{array}$ & $\begin{array}{l}\text { Time } \\
\left({ }^{\circ} \mathrm{C}\right)\end{array}$ & $\begin{array}{c}\text { Temperature } \\
\left({ }^{\circ} \mathrm{C}\right)\end{array}$ & $\begin{array}{l}\text { Time } \\
\text { (hr) }\end{array}$ \\
\hline 21 & 5 & $700-710$ & $105-120$ & 580 & 8 & 180 & 8 \\
\hline
\end{tabular}


polished by sanding from 320 grid to 2500 gray. Afterwards, electrolytic etching was performed in order to analyze the grain size.

\subsection{Mechanical Test}

\subsubsection{Tensile Test}

In the experimental study, the tensile strength and yield strength tests of the samples which were subjected to excessive aging were performed on a Zwick/Roell brand $50 \mathrm{Kn}$ tensile device.

\subsubsection{Hardness Test}

Vickers $\left(\mathrm{HV}_{1}\right)$ hardness measurements were made on the samples with the Future-Tech Microhardness device.

\section{Result and Discussion}

\subsection{Microstructure Analysis Result}

It was observed that the coarse grains in the microstructure of the AA6082-T6 alloy with Sample 1 using by optical microscopy. The dark part displays the rich area in term of $\mathrm{Al}$ and $\mathrm{Si}$. It has thougt that the part which in the grain boundaries increases the strength of the material. Figure 1 shows the particle size of the sampled analyzed with a mean value of $323 \mu \mathrm{m}$.

It was determined that by adding $0.09 \% \mathrm{AlTi}_{5} \mathrm{~B}_{1}$ master alloy to the 6082 alloy in the sample numbered 2, it was observed that there was a reduction in the particle sizes. The mean value value was measured as $201 \mu \mathrm{m}$ under a microscope (Figure 2). Figure 3 shows the mean value was measured $98 \mu \mathrm{m}$ with the contribution of $\mathrm{Mg}$ and $\mathrm{AlTi}_{5} \mathrm{~B}_{1}$ to the 6082 alloy for Sample 3. Figure 4 shows the grain size was measured $171 \mu \mathrm{m}$ with only $\mathrm{Mg}$ addition for Sample 4. Also Figure 5 shows the grain size was measured $150 \mu \mathrm{m}$ with only $\mathrm{Cr}$ addition for sample number 5 .

\subsection{Mechanical Test Result}

Billets casting with five different alloys are shaped by the extrusion process. Heat

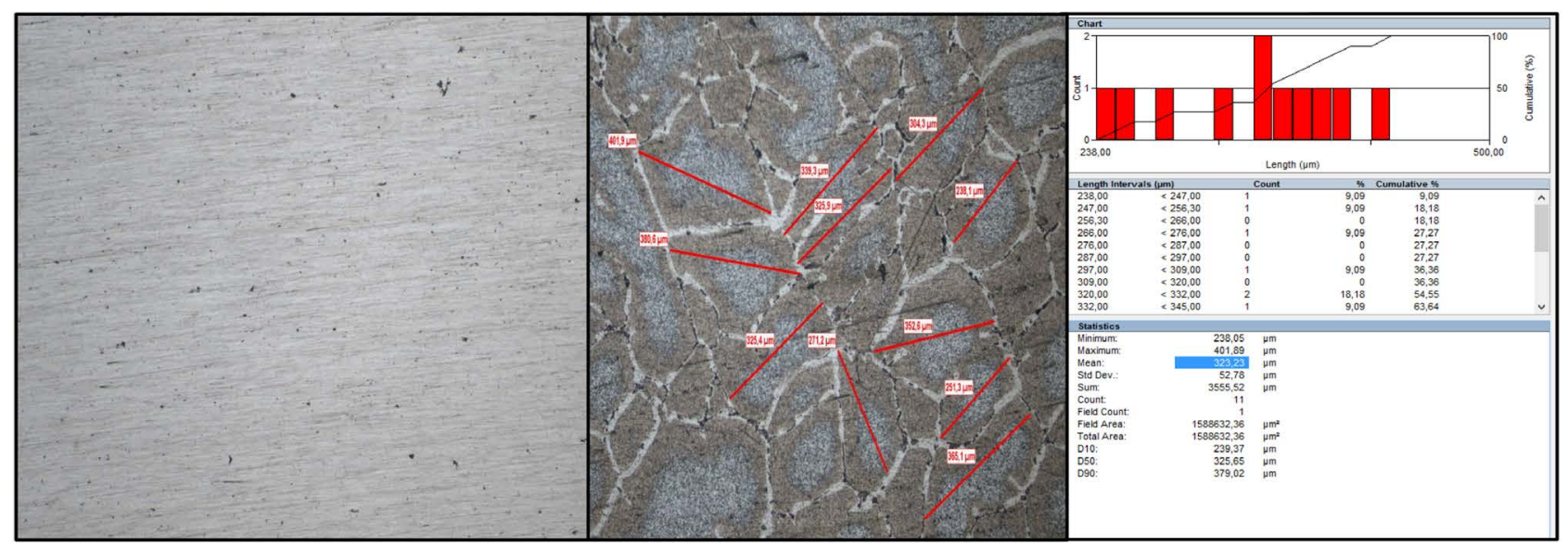

Figure 1. Microstructure analysis (Sample 1). 


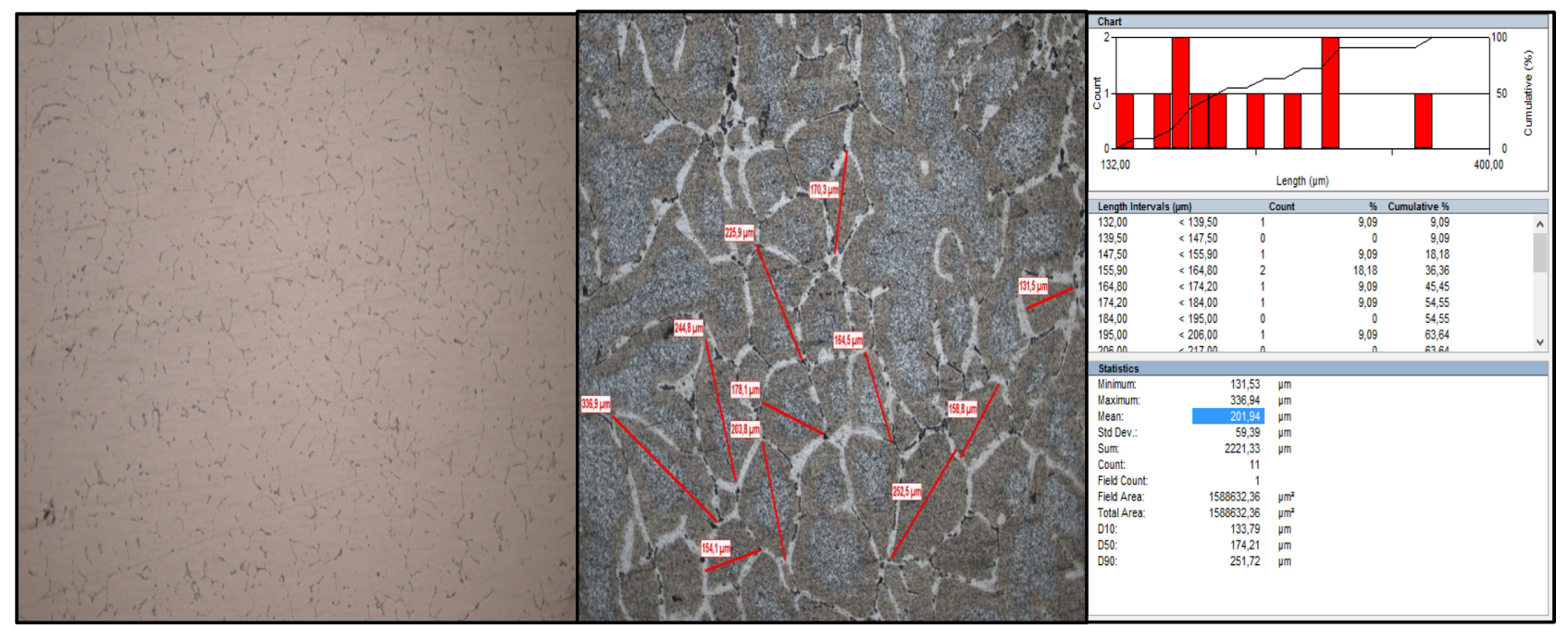

Figure 2. Microstructure analysis (Sample 2).
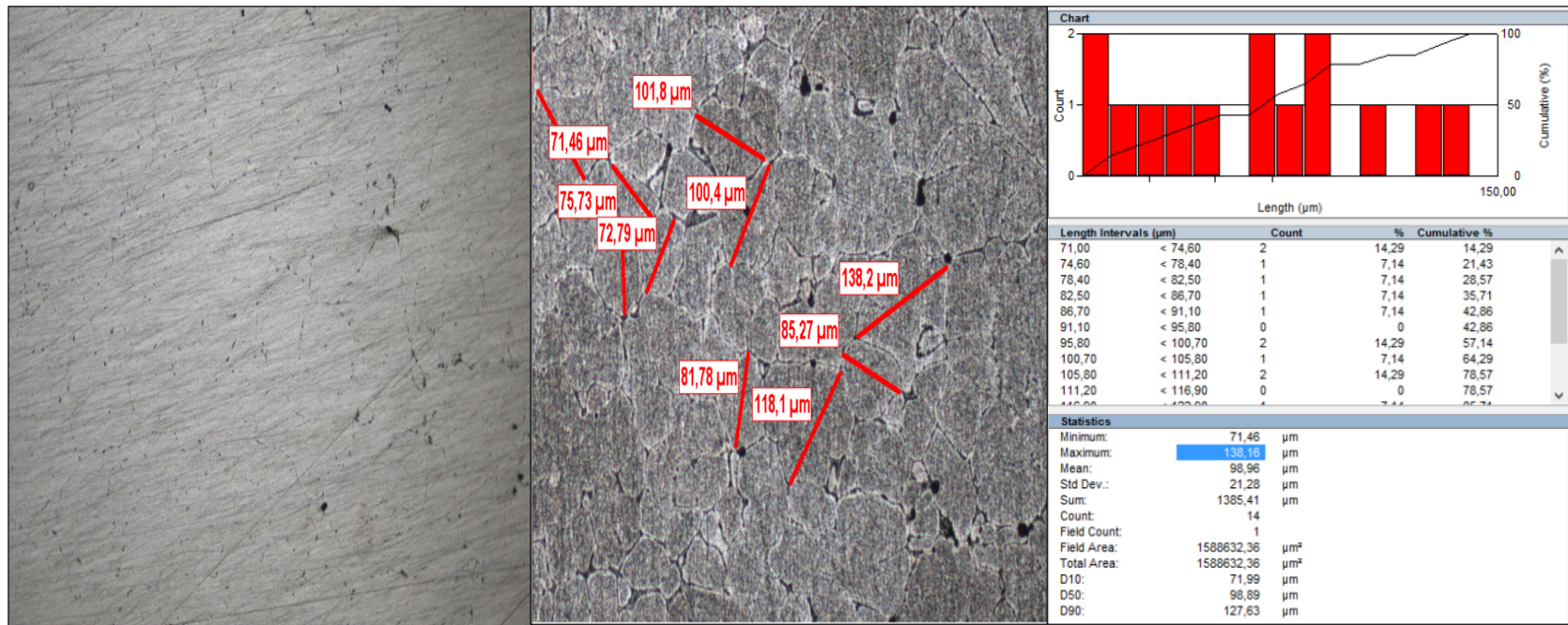

Figure 3. Microstructure analysis (Sample 3).
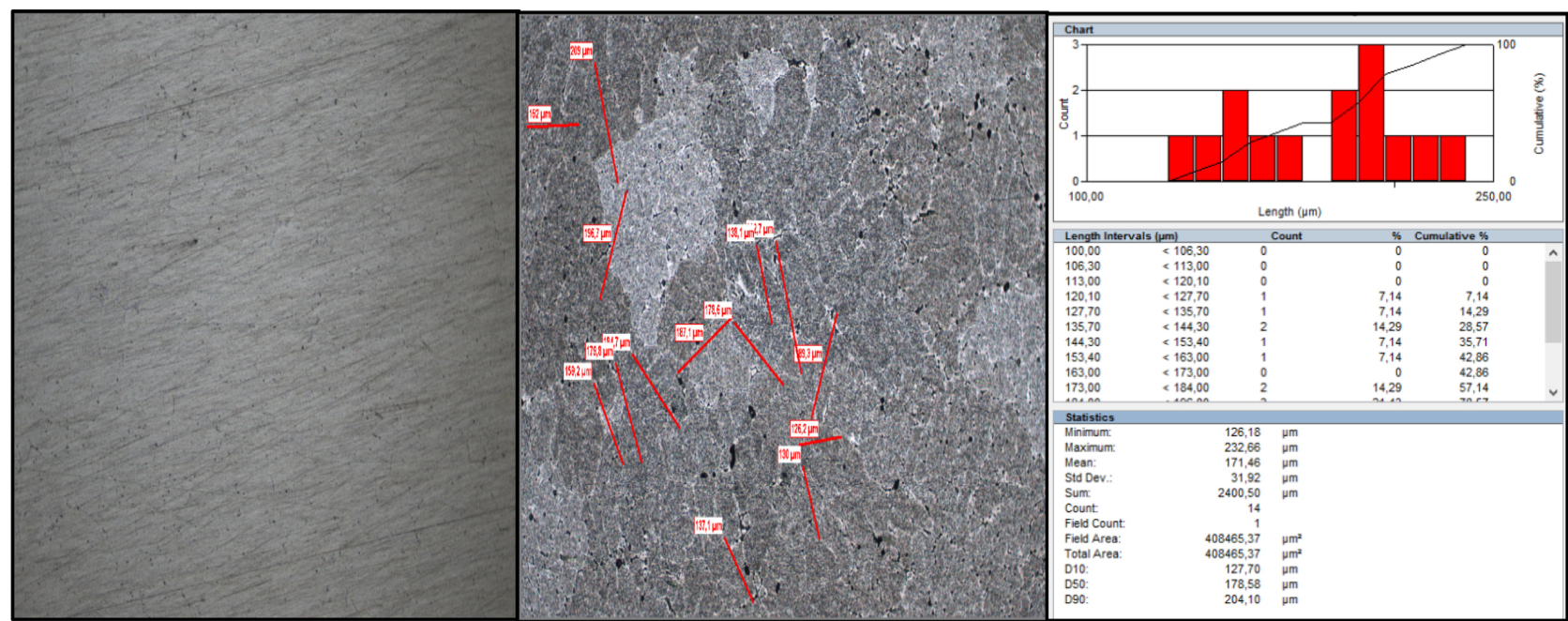

Figure 4. Microstructure analysis (Sample 4). 


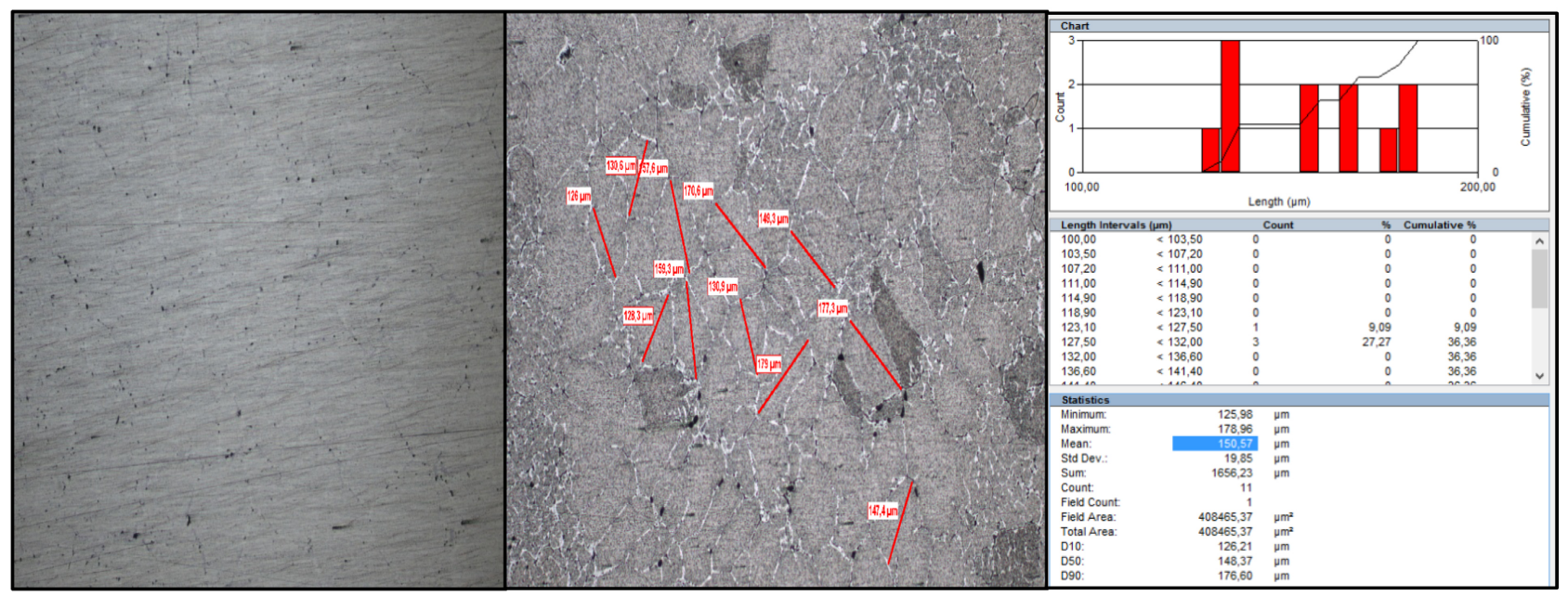

Figure 5. Microstructure analysis (Sample 5).

Table 5. Mechanic test results.

\begin{tabular}{cccc}
\hline Sample Number & $\begin{array}{c}\text { Tensile Strength } \\
\mathrm{R}_{\mathrm{m}}(\mathrm{Mpa})\end{array}$ & $\begin{array}{c}\text { Yield Strength } \\
\text { Rpo, 2 (Mpa) }\end{array}$ & $\begin{array}{c}\text { Hardness } \\
(\text { HBW })\end{array}$ \\
\hline Sample 1 & 295 & 255 & 84 \\
Sample 2 & 315 & 267 & 87 \\
Sample 3 & 342 & 296 & 96 \\
Sample 4 & 324 & 272 & 90 \\
Sample 5 & 336 & 283 & 89 \\
\hline
\end{tabular}

treatment studies have been completed in the drying oven under laboratory conditions and samples are mechanically tested. The mechanical values obtained as a result of the test are given in Table 5 .

\section{Conclusion}

In this study, it was aimed to understand the effect of the increment in the nucleation and refining the grain size on the mechanical properties of the AA6082. To do so, AlTiB master alloys, $\mathrm{Mg}$, and $\mathrm{Cr}$ were added at different content to determine possible improvement of mechanical properties such as hardness and strength. The particle size of the elemental amount in the composition was examined by adding the elements used as grain refiner to the liquid metal in the aluminum alloy casting process, and it was tried to investigate to what ratio the grain size affects the mechanical properties. When 6082 aluminum alloy was examined without extra additions, it was observed that the grain sizes were large. Proportional reduction in grain sizes with $\mathrm{Mg}, \mathrm{Cr}$ and $\mathrm{AlTi}_{5} \mathrm{~B}_{1}$ additives was supported by tests and analyzes. It has been observed that by increasing the additional amounts, the grains become finer and therefore the grain size is directly related to the amount of grain refiner. Considering the effects of grain refining on the mechanical properties, it was seen that the alloy with $1.20 \% \mathrm{Mg}$ content reached the Titanium-boron master alloy heading the highest tensile 
strength value.

\section{Conflicts of Interest}

The authors declare no conflicts of interest regarding the publication of this paper.

\section{References}

[1] Akyüz, B. and Şenaysoy, S. (2014) Effect of Aging on Mechanical Properties and Machining on Aluminum Alloys. Bilecik Şeyh Edebali Üniversitesi Fen Bilimleri Dergisi.

[2] Lu, L., Dahle, A.K. and StJohn, D.H. (2005) Grain Refinement Efficiency and Mechanism of Aluminium Carbide in Mg-Al Alloys. Scripta Materilia, 53, 517-522. https://doi.org/10.1016/j.scriptamat.2005.05.008

[3] Ilgaz, O. (2014) Döküm Ekstrüzyon ve Dövme İşlemlerinin 6082 Al Alaşımlı Dövme Süspansiyo Parçalarında Mikroyapı ve Mekanik Özelliklere Etkisi. MsC Thesis, Selçuk Üniversitesi Fen Bilimleri Enstitüsü Metalurji ve Malzeme Mühendisliği.

[4] Kahrıman, F. (2018) Zirkonyum ile Modifiye Edilmiş EN AW 6082 Alüminyum Alaşımının Çökelme ve Yeniden Kristallenme Kinetiklerinin İncelenmesi. PhD Thesis, Kocaeli Üniversitesi Fen Bilimleri Enstitüsü Metalurji ve Malzeme Mühendisliği.

[5] Güven O. (2005) Alüminyum Silisyum Magnezyum Döküm Alaşımlarının Yapı İncelemesi. MsC Thesis, İstanbul Teknik Üniversitesi Fen Bilimleri Enstitüsü, Metalurji ve Malzeme Mühendisliği.

[6] Yıldırım, M. and Özyürek, D. (2013) The Effects of Mg Amount on the Microstructure and Mechanical Properties of Al-Si-Mg Alloys. Materials and Design, 51, 767-774. https://doi.org/10.1016/j.matdes.2013.04.089

[7] Thiago, M.R., Catellan, E., Garcia, A. and Carlos, A. (2020) The Effects of Cr Addition on Microstructure, Hardness and Tensile Properties of As-Cast Al-3.8 wt. \%Cu-(Cr) Alloys. Journal of Materials Research and Technology, 9, 6620-6631.

[8] Mohanty, P.S. and Gruzleskı, L.E. (1994) Mechanism of Grain Refinement in Aluminium. Acta Metallurgica et Materialia, 43, 2001-2012. https://doi.org/10.1016/0956-7151(94)00405-7

[9] Sunitha, K. and Gurusami, K. (2020) Study of 1-Si Alloys Grain Refinement by İnocluation. Materials Today. Proceedings, 43, 1825-1829. https://doi.org/10.1016/j.matpr.2020.10.684

[10] Çolak, M. and Kayıkçı, R. (2009) Alüminyum Dökümlerde Tane İnceltme, SAÜ. Fen Bilimleri Dergisi.

[11] Nadendla, H.B., Nowak, M. and Bolzoni, L. (2013) Grain Refiner for Al-Si Alloys. Light Metals 2013. https://doi.org/10.1002/9781118663189.ch170

[12] Zhao, G., Xu, S., Luan, Y., Guan, Y., Lun, N. and Ren, X. (2006) Grain Refinement Mechanism Analysis and Experimental İnvestigation of Equal Channel Angular Pressing for Producing Pure Aluminium Ultra-Fine Grained Materials. Materials Science and Engineering: A, 437, 281-292.

https://doi.org/10.1016/j.msea.2006.07.138 